\title{
God and emotions: Experience of emotive analysis
}

\author{
Sergey M. Pashkov \\ Herzen State Pedagogical University (Volkhov branch) \\ Volkhov, Russia
}

\begin{abstract}
The present paper accentuates the importance of holistic views of the world that is relevant for text studies. The purpose of the study is to establish what language means representing emotions which are attributed to God by biblical characters are utilized, and, subsequently provide their classification. Based on the study of the theological interpretation of the antinomy " "the immutability of God" - the emotions of God", the paper 1) introduces the concept of 'attribution of emotions' into the conceptual and terminological apparatus of emotiology thus explicating the specificity of biblical emotive meanings; 2) provides the analysis of the depicted biblical space in the emotive aspect; 3 ) gives the interpretation of biblical characters' activity as a cause of emotions attributed to God. Central to the text analysis is the notion of the emotional script. This notion is instrumental in presenting the systemic description of emotion development, i.e. the cause of its origin and the corresponding reaction. The language material of the present study is taken from King James Bible. The methods employed in the study include the definitional, contextual, emotive, and lingua-stylistic analyses with references to the historical and cultural context. The outcomes of the present study include the identification of the lexical means of emotions and the following typology of such lexical units: 1) lexemes denoting the cause of emotions attributed to God; 2) lexemes denoting the emotions attributed to God; and 3) lexemes denoting the biblical space perceived by characters as a 'reaction' to emotions attributed to God. Given the theandric nature of Jesus Christ, the depicted emotions of His are treated as manifestations of His human nature. The results obtained have made it possible to fill in linguistic content into one of the antinomies of Christian understanding of God and to outline the prospect of further linguistic research on Christian dogmata from the perspective of emotivity.
\end{abstract}

Keywords: The Bible, attribution of emotions, emotivity, evaluation, emotional script, context, biblical space

\section{For citation:}

Pashkov, Sergey M. 2020. God and emotions: Experience of emotive analysis. Russian Journal of Linguistics 24 (2). 449-466. DOI: 10.22363/2687-0088-2020-24-2-449-466 
Научная статья

\title{
Бог и эмоции: опыт эмотивного анализа
}

\section{С.М. Пашков}

Российский государственный педагогический университет им. А.И. Герцена

(Волховский филиал)

Волхов, Россия

\begin{abstract}
Аннотация
В статье акцентируется значимость холистических взглядов на мир при исследовании проблем текста. Цель статьи - проанализировать и систематизировать языковые репрезентанты эмоций, атрибутируемых Богу библейскими персонажами. На основе изучения богословского понимания антиномии «неизменность Бога - эмоции Бога» в статье обосновывается: 1) введение термина «атрибуция эмоций» в понятийно-терминологический аппарат лингвистики эмоций, эксплицирующего специфику библейских эмотивных смыслов; 2) рассмотрение изображенного библейского пространства в эмотивном аспекте; 3) интерпретация изображенной деятельности библейских персонажей в качестве причины эмоций, атрибутируемых Богу. Языковой материал анализируется с опорой на понятие эмоционального сценария, позволяющего представить системное описание развития эмоции, то есть причину ее появления и реакцию. Материалом исследования послужил англоязычный текст Библии короля Якова. Методы исследования языкового материала включают дефиниционный, контекстуальный, эмотивный и лингвостилистический анализы с привлечением факторов широкого историко-культурного контекста. В результате исследования автором установлены и систематизированы: 1) языковые средства, репрезентирующие причины эмоций, атрибутируемых Богу; 2) языковые средства репрезентирующие эмоции, атрибутируемые Богу; 3) языковые средства, репрезентирующие пространство, воспринимаемое библейскими персонажами как «реакция» на атрибутируемые Богу эмоции. Учитывая Богочеловеческую природу Иисуса Христа, Его изображенные эмоции рассматриваются как проявления человеческой природы. Полученные результаты позволили наполнить языковым содержанием одну из антиномий христианского понимания Бога и наметить перспективу дальнейшего лингвистического исследования христианской догматики в эмотивном ракурсе.
\end{abstract}

Ключевые слова: Библия, атрибуция эмочий, эмотивность, оценочность, эмоциональньй сиенарий, контекст, библейский топос

\section{Для цитирования:}

Пашков С.М. Бог и эмоции: опыт эмотивного анализа // Russian Journal of Linguistics. 2020. T. 24. № 2. C. 449 — 466. DOI: 10.22363/2687-0088-2020-24-2-449-466

$<\ldots>$ Love your enemies, bless them that curse you, do good to them that hate you, and pray for them which despitefully use you, and persecute you; That ye may be the children of your Father which is in heaven: for he maketh his sun to rise on the evil and on the good, and sendeth rain on the just and on the unjust

(Matthew, 5: 44-45). 


\section{1. Введение}

В современной лингвистической науке наблюдается значительный рост исследований, посвященных взаимодействию языка и религии. Среди основных направлений в этой области знания выделяются теолингвистика, лингвоперсонология, лексикография, а также языковая вариативность в религиозной сфере (Найденова 2018). Одним из важнейших религиозных артефактов для исследователей, безусловно, является Библия. Особый интерес текст Библии представляет для эмотиологии, поскольку эмоциональная функция религиозного дискурса рассматривается в качестве одной из ведущих (Бобырева 2015: 53).

Исследование категории эмотивности на материале библейского текста позволило установить в нем два блока репрезентируемых эмоций: нуминозные и ануминозные. Первые - всегда положительные, вторые - положительные / отрицательные. Данные эмоции библейский персонаж испытывает либо по отношению к Богу (нуминозные), либо по отношению к другому человеку / объекту (ануминозные); их реализация, таким образом, осуществляется в координатах «человек $\rightarrow$ Бог» и «человек↔человек» (Пашков 2018). Однако в христианстве постулируется личное отношение Бога к человеку, Его диалогическое самораскрытие в актах Откровения (Аверинцев 2006: 109). В связи с этим положением представляется актуальным выявление специфики репрезентации категории эмотивности в координате «Бог $\rightarrow$ человек», не получившее достаточное освещение в лингвистической литературе.

\section{2. Сущностные свойства Бога}

Исследование сложных структур, к которым, несомненно, относится текст, не представляется возможным без холистического взгляда на мир. Методологически холизм заключается в интеграции между науками, а также наукой и культурой (Князева 2016: 23). Необходимость выхода в междисциплинарный контекст при решении научных проблем коррелирует с одним из базовых положений лингвистики эмоций, а именно тезисом о константной связанности эмотивной семантики, интерпретация которой требует контекстуализации (Шаховский 2009: 155, 173). В связи с этим положением достижение цели настоящего исследования требует уточнения представлений о Боге в христианстве.

В религиозных учениях Бог - Высшее Существо, создающее и устрояющее мир. В христианстве Бог понимается как Личность, сущность Которого едина, но бытие - это личностное отношение трех Ипостасей: Отец - безначальное первоначало, Сын - Логос, воплотившийся в Иисусе Христе и Дух Святой - «животворящее» начало. Три Ипостаси репрезентируются лексемой Троииа (Аверинцев 2006: 109, 448). В христианской теологии постулируется Богочеловеческая природа Иисуса Христа, имеющего полноту Божественной природы и всю конкретность человеческой природы (там же: 201) (ср. природу Гильгамеша «На две трети — бог, на одну — человек он»). 
Согласно библейской точке зрения Бог непознаваем, однако Он обладает определенными свойствами, о которых повествуется в текстах Библии. В классическом теизме выделяются такие свойства Бога как совершенство, вневременность, неизменность, всемогущество и всеведение (Pojman \& Rea 2012: 60). Поскольку в статье анализируются языковые средства репрезентации «эмоций» Бога, а эмоции - суть «психические процессы» (Леонтьев 1970: 553), предполагающие изменение, релевантным является свойство Бога, определяемое как неизменность.

Неизменность Создателя понимается как отсутствие чего-либо внешнего, что способно Его изменить (ББС 2005: 195). О неизменности Творца пишет пророк Малахия: «Ибо Я - Господь, Я не изменяюсь» (Мал. 3: 6). Однако в тексте Библии репрезентируются различные «эмоции» Бога, которые Он «испытывает» по отношению к человеку. Так, Всевышний описывается как любящий, милостивый, прощающий, разгневанный и пр. (Werblowsky 2005: 389).

При изучении языка религии необходимо помнить о его метафоричности. Особенно метафоры часты, когда речь идет о тайне Создателя. Отмечается, что фактически все антропоморфизмы являются метафорами (Библиологический словарь 2002: 476). Одним из видов антропоморфизма рассматривается антропопатизм, под которым понимается «приписывание Богу страстей и душевных состояний» (Аверинцев 2006: 57) (курсив мой - С.П.). Тезис об отсутствии эмоций у Бога, характерный для традиционного богословия, конкретизируется в доктрине бесстрастности Бога (The Doctrine of impassibility) (Extrom 2012: 395). В ее защиту категорично пишет преподобный Антоний Великий: «Бог не радуется и не гневается, ибо радость и гнев суть страсти. Нелепо думать, чтобы Божеству было хорошо или худо из-за дел человеческих. Бог благ и только благое творит, вредить же никому не вредит, пребывая всегда одинаковым; а мы, когда бываем добры, то вступаем в общение с Богом - по сходству с Ним, а когда становимся злыми, то отделяемся от Бога - по несходству с Ним» (цит. по: Осипов 2014: 16).

\section{3. Атрибуция эмоций как способ познания}

Метаязык современной лингвистики эмоций хорошо разработан и охватывает многие явления в сфере эмоциональной коммуникации. Однако языковая репрезентация эмоций в рамках координаты «Бог $\rightarrow$ человек» терминологически не эксплицирована. Так, среди прочего, В. И. Шаховский рассматривает «имитацию эмоций» и «симуляцию эмоций» в качестве ключевых терминопонятий лингвистики эмоций (Шаховский 2010: 6), однако они не раскрывают сущность эмоций, исследуемых в данной статье. Во-первых, ЛЕ (лексическая единица) имитация и симуляция характеризуются наличием отрицательных оценочных сем. Ср.:

- симуляция: 'притворство, ложное утверждение или изображение чегон. с целью ввести в обман, в заблуждение'; 
- имитация: 'подделка подо что-н.' (Толковый словарь русского языка 1997: 245, 717) (Здесь и далее курсив в дефинициях мой - C.П.).

Во-вторых, данные терминопонятия не объясняют функциональную направленность изображенных «эмоций» Творца. Если симуляция и имитация эмоций - всегда в той или иной степени введение адресата в обман, то рассматриваемые библейские эмоции - способ объяснения человеком мира и своего существования в нем. «Пока человек остается земнородным существом, - душевно-телесным, протяженно-пространственным, личным и множественным, - ему неизбежно вводить созерцаемого им Бога в свои «категории», как бы «выражать» Его на языке своей земнородности» (Ильин 2002: 343) (курсив мой - С.П.).

В свете сказанного представляется возможным ввести в понятийнотерминологический аппарат лингвистики эмоций термин атрибуциия эмоций, позволяющий адекватно описать эмотивные библейские смыслы в координате «Бог $\rightarrow$ человек» (ср. выше фразеологию С.С. Аверинцева о приписывании Богу страстей). В социальной психологии суть атрибуции видится в попытке «интерпретировать социальный объект, понять его поведение в условиях дефицита информации путем домысливания» (Большой психологический словарь 2003: 39) (курсив мой - С.П.). Причем результат атрибуции может быть как истинным, так и ложным. Применительно к библейскому тексту атрибуция эмоций Богу вызвана дефицитом информации того или иного персонажа о сущности Бога - персонажа, пытающегося познать изменения в мире и в самом себе в процессе своей деятельности. Эта деятельность либо сокращает, либо увеличивает дистанцию между ним и Богом. В первом случае он имеет благо и атрибутирует Творцу положительные эмоции. Во втором - злоключения, приписывая Ему отрицательные переживания.

Следует отметить, что эвристическая ценность понятия атрибуции эмоций не ограничивается его использованием при интерпретации библейского текста. Обращение к нему оправдано и при анализе художественных текстов (ср. рассказ А. П. Чехова «Смерть чиновника», а также исследование мыслейэмоций В. И. Шаховского) (Шаховский 2008: 247).

\section{4. Библейский топос в эмотивном аспекте}

Моделирование «внутреннего мира» посредством пространственных особенностей, изображенных в художественном тексте, получило широкое освещение в литературоведческих и лингвистических трудах. По мнению А. Крейцера, абстрактные сущности, в том числе и эмоции, регулярно концептуализируются посредством пространственных образов (цит. по: Zlatev 2007: 319). Так, в исследовании (Щирова 2003) показано моделирование когнитивных процессов сквозь призму пространственных координат, конституируемых с помощью эстетически значимых компонентов художественного 
образа - деталей. Этот «символизм» природных явлений и пространственных особенностей, характерный для художественного текста, библейскому тексту чужд.

Содержательное наполнение понятия земли (пространство) в тексте Библии шире, чем в современном языке. Отмечается, что гебраизм, переводимый как «земля», является также родовым названием человека: Адам (North 2001: 3). Эта сущностная связь человека и земли объясняет тот факт, что благополучие и несчастье персонажа в тексте Библии в первую очередь осмысляется сквозь призму пространственных координат. Так, первородный грех Адама влечет разрыв интимных отношений с Богом, Которому чужд грех. Причем не Творец удаляется от твари, но сама согрешившая тварь бежит от Него (ср. «И услышали голос Господа Бога, ходящего в раю во время прохлады дня; и скрылся Адам и жена его от лица Господа Бога между деревьями рая»). Как следствие, жизнь Адама и последующих поколений становится суровой и унылой (Whybray 2000: 43). Позднее, согласно закону Моисея, земля становится «духовнылм барометром» для древних израильтян, который фиксировал состояние их отношений с Богом (ББС 2005: 496) (курсив мой - С.П.). В Новом Завете эта зависимость нивелируется, однако не устраняется полностью (ср. слова Христа «Ищите же прежде Царства Божия и правды Его, и это всё (благосостояние - С.П.) приложится вам»). В логике сказанного можно констатировать следующее: функциональной направленностью библейского топоса является маркирование сущностной связи между духовно-нравственным поведением человека и окружающим его материальным миром.

При анализе языковых репрезентантов библейского пространства необходимо отметить следующее. Общеизвестны две концепции пространства субстанциальная (Ньютон) и реляционная (Декарт, Лейбниц, Мах). Согласно первой концепции пространство понимается как нечто первичное, не зависящее от конфигурации материальных объектов, заполняющих его. В соответствии со второй концепцией пространство воспринимается как совокупность отношений, образуемых взаимодействием материальных объектов (Топоров 1983: 228). Если в первом случае пространство является объективацией идеи 'пространства', то во втором - оно «прочитывается» человеком (Яковлева 1994: 18). В нашем исследовании библейской лингвистики мы будем понимать пространство как взаимодействие различных материальных объектов.

Идею «прочитывания» пространства, в том числе, добавим от себя, «эмоционального прочитывания», находим у М.М. Бахтина. Мыслитель отмечает, что вещь может воздействовать на личность, если она раскрывает свой смысловой потенциал и становится «словом» (Бахтин 1986: 387) (курсив мой - С.П.). Мысли М.М. Бахтина созвучны размышления В.И. Шаховского. Любая деятельность, в том числе речь, пронизана эмоциями. Поскольку язык, заключает В.И. Шаховский, вплетен в любую деятельность, то «эмоции представлены не только в словах, но и в памяти, в звуке, в музыке, в металле, в ткани, в свете, в запахе и других формах...» (Шаховский 2010: 13) (курсив 
мой - С.П.). Взгляды М.М. Бахтина и В.И. Шаховского особенно релевантны для лингвистического анализа библейского пространства. «Вещная среда» (М.M. Бахтин) текста Библии эмоционально нагружена, становится словом и «разговаривает» с персонажем о его отношениях с Богом. Необходимо отметить, что библейское пространство конституируется не только изображаемыми объектами, но и персонажами. Этот тезис перекликается с мнением И.Р. Гальперина, который относит к пространственным параметрам также действующих лиц (Гальперин 2007: 95).

\section{5. Методика исследования}

Общеизвестно, что лингвистическое описание эмоций в целостном тексте позволяет полнее раскрыть семантический потенциал категории эмотивности, поскольку в речи отражается больше, чем заложено в системе (Филимонова 2007: 22). В отечественной лингвистике эмоций детально разработан метод эмотивного анализа и заключается в выделении названных, описанных, выраженных эмоций, а также в определении оценочного знака эмотивов (Шаховский, 2009).

При анализе текстового материала продуктивно обращение к понятию эмоционального сценария, позволяющее системно описать развитие эмоции, то есть причину ее появления и реакцию. Под сценарием эмоции понимается ряд развивающихся событий, которые особым образом темпорально и каузально соотнесены (Kövecses, Palmer \& Dirven 2003: 140). Обычно выделяются три основных компонента сценария эмоции: причина, эмоция, реакция. Применительно к исследуемому материалу компонент 'причина' реализуется посредством языковых средств, репрезентирующих явления внеязыковой действительности, вызывающие определенную эмоцию; компонент 'эмоция' - посредством обозначения, описания и выражения эмоций; компонент 'реакция' связывается с использованием языковых средств, репрезентирующих библейское пространство.

Принимая во внимание вышесказанное, представляется возможным выделить следующие лексемы, репрезентирующие развитие эмоций, атрибутируемых Богу:

$>$ причина: лексемы, репрезентирующие порочную / благочестивую жизнь персонажа;

> эмоция: лексемы, репрезентирующие отрицательные / положительные эмоции;

$>$ реакция: лексемы, репрезентирующие неблагоприятное / благоприятное пространство.

Следует отметить, что компонент сценария 'эмоция' не всегда выражен эксплицитно. Его декодирование осуществляется посредством анализа языковых репрезентантов, актуализирующих компоненты 'причина' и 'реакция'. 


\section{6. Репрезентация отрицательных эмоций}

В тексте Библии описывается множество заповедей, соблюдение которых обеспечивает человеку гармонию с Творцом и близость к Нему. Любовь к Богу и любовь к ближнему рассматриваются важнейшими нормами поведения (заповедями), определяемые как суперморальные и моральные соответственно (Карасик 2002: 224). Их несоблюдение ведет к преступлениям духа и плоти, актуализирующими первый этап эмоционального сценария ('причина') и репрезентируемые посредством: а) лексики с абстрактной семантикой (evil, gods, wickedness, lies, sin); б) лексики с ментальной семантикой (forgotten, (not) kept, hearken (not), imagination, thoughts (evil)); в) лексики с акциональной семантикой (serve, committed, cut off, sacrificed, built, burnt, did). Выделенные три группы лексем характеризуются отрицательной оценочностью различного статуса. Если абстрактная лексика имеет узуальную отрицательную оценку, то ментальная и акциональная лексика - окказиональную.

Отрицательные эмоции, атрибутируемые Богу, актуализируют второй этап эмоционального сценария ('эмоция') и репрезентируются через: a) обозначение (sorrow, anger, indignation, wrath, fury, displeasure, jealousy); б) описание (repented, grieved, abhorred, hatest, despise, displeased, angry, wroth); в) выражение (horrible, abominable).

Лингвистический анализ библейского текста позволяет утверждать, что подавляющее большинство атрибутируемых Богу эмоций характеризуется отрицательной направленностью, причем эмоция гнева репрезентируется чаще других. Известно, что гнев может рассматриваться и как положительная эмоция, однако в религиозном дискурсе его отрицательная оценка доминирует (Волкова, Панченко 2018: 180). В тексте Библии гнев в основном обозначается лексемой anger. Видимо, это объясняется тем, что данная ЛЕ является базовой для обозначения ситуаций, когда совершается нечто предосудительное (Wierzbicka 1992: 569).

Дисгармония библейского пространства, актуализирующая третий этап сценария эмоции ('реакция'), репрезентируется с помощью лексики с локальной семантикой (city, earth, Judah, streets, Jerusalem, land, high place). Эти лексемы характеризуются окказиональной отрицательной оценкой в микроконтекстах, репрезентирующих отрицательные эмоции, атрибутируемые Богу.

(1) 'And GOD saw that the wickedness of man was great in the earth, and that every imagination of the thoughts of his heart was only evil continually. And it repented the LORD that he had made man on the earth, and it grieved him at his heart. And the LORD said, I will destroy man whom I have created from the face of the earth; both man, and beast, and the creeping thing, and the fowls of the air; for it repenteth me that I have made them' (Genesis, 6: 5-7).

В микроконтексте № 1 изображается важное событие библейской истории - намерение Бога навести потоп на землю по причине порочной жизни людей. ЛЕ с абстрактной (wickedness) и ментальной (imagination, thoughts) ceмантикой репрезентируют преступления духа. Эпитет evil с отрицательной 
оценкой и эмоционально-усилительное прилагательное great изображают глубину духовного падения людей, а ЛЕ only и continually свидетельствуют об их исключительной и постоянной злонамеренности.

Порочная жизнь людей вызывает эмоции сожаления и печали: они описываются глаголами repented, repenteth и grieved, содержащими в своих значениях семы 'regret' и 'grief'. Сp.:

- repent(ed): 'to cause to feel regret or contrition';

- grieve(d): 'to feel or show grief over' (Merriam-Webster Dictionary, далее - M-W).

Бог «раскаялся» и «восскорбел», что создал человека. Атрибуция данных переживаний Создателю реализуется с помощью комплетивной связи (grieved him, repented the LORD). К языковым средствам описания третьего этапа сценария оправданно отнести ЛЕ с локальной семантикой earth, beast, thing, fowls и man. Объекты и люди, номинируемые данными существительными, обречены на уничтожение (I will destroy), и это, безусловно, свидетельствует о дисгармонии в отношениях творения и Творца.

(2) 'Then did Solomon build an high place for Chemosh, the abomination of Moab, in the hill that is before Jerusalem, and for Molech, the abomination of the children of Ammon. And likewise did he for all his strange wives, which burnt incense and sacrificed unto their gods. And the LORD was angry with Solomon, because his heart was turned from the LORD God of Israel, which had appeared unto him twice, $<\ldots>$. Wherefore the LORD said unto Solomon, Forasmuch as this is done of thee, and thou hast not kept my covenant and my statutes, which I have commanded thee, I will surely rend the kingdom from thee, and will give it to thy servant' (First Kings, 11: 7-11).

В микроконтексте № 2 изображается нарушение царем Соломоном и его женами первой заповеди Декалога - поклонение другим богам. ЛЕ с абстрактной (gods), ментальной (not kept) и акциональной (sacrificed, built, burnt, $d i d)$ семантикой репрезентируют преступления духа и плоти. Соломон строит капища богам (an high place), а его жены кадят и приносят им жертвы (burnt incense and sacrificed unto their gods).

Эти преступления царской семьи «вызывают» у Бога эмоцию гнева, которая описывается лексемой angry. Данная эмоция атрибутируется Создателю посредством предикативной связи (the LORD was angry). ЛЕ abomination, номинирующая языческих богов (abomination of Moab, abomination of the children of Ammon), также свидетельствует о богопротивной деятельности царя (ср. abomination: 'something regarded with disgust or hatred' $(\mathrm{M}-\mathrm{W}))$.

Актуализация третьего этапа сценария реализуется посредством существительного с локальной семантикой kingdom, описывающего царство Соломона; Бог обещает отторгнуть его от царя по причине вероотступничества 
(I will surely rend the kingdom from thee). ЛЕ Wherefore и Forasmuch as маркируют эту причинно-следственную связь и акцентируют сущностную зависимость состояния библейского пространства от деятельности персонажа.

(3) 'Because of their wickedness which they have committed to provoke me to anger, in that they went to burn incense, and to serve other gods, whom they knew not, neither they, ye, nor your fathers. Howbeit I sent unto you all my servants the prophets, rising early and sending them, saying, Oh, do not this abominable thing that I hate. But they hearkened not, nor inclined their ear to turn from their wickedness, to burn no incense unto other gods. Wherefore my fury and mine anger was poured forth, and was kindled in the cities of Judah and in the streets of Jerusalem; and they are wasted and desolate, as at this day. Therefore now thus saith the LORD, the God of hosts, the God of Israel; Wherefore commit ye this great evil against your souls, to cut off from you man and woman, child and suckling, out of Judah < .. >' (Jeremiah, 44: 3-7).

В микроконтексте № 3 изображаются преступления духа и плоти избранного народа. Нечестие, поклонение идолам, истребление взрослых и детей репрезентируются ЛЕ с абстрактной (thing, gods, wickedness, evil), ментальной (nor inclined their ear, hearken (not)) и акциональной (serve, burned, done, committed, cut off) семантикой.

Ненависть, гнев и ярость, формирующие второй этап сценария, обозначаются существительными anger, fury и описывается эмоциональным глаголом hate. Гнев Творца вербализуется в виде горячей жидкости, изливаемой на еврейские города (was poured, was kindled). Отмечается, что метафорически гнев концептуализируется в первую очередь как горячая жидкость (ANGER IS A HOT FLUID IN A CONTAINER) (Kövesces 2000: 22). Эмоционально-усилительное прилагательное abominable, выражающее отвращение Создателя к преступлениям человека (abominable thing), позволяет поставить необходимый эмоциональный акцент — идолопоклонство как тяжкое преступление против Бога. Атрибуция данных эмоций реализуется посредством предикативной связи (I hate) и местоимений (my fury and mine anger). Следует отметить, что междометие $O h$, также выражающее отвращение Бога, отсутствует в соответствующем древнееврейском тексте (ср. также Вульгату и Синодальный перевод). Возможно, его использование в английском переводе объясняется влиянием литературных традиций второй половины XVI — начала XVII веков. Так, в исследовании (Marx 2000: 1), хотя и ставится под сомнение влияние Шекспира на Библию короля Якова, однако категорично не отрицается (ср. 'It is unlikely that Shakespeare had a hand in this project, but not impossible.').

Третий этап сценария эмоции формируется описанием бедствий, которые евреи вынуждены терпеть. Нейтральные в узусе лексемы с локальной семантикой (cities, Judah, streets, Israel, Jerusalem, land), соположенные с отрицательными эпитетами (wasted, desolate), приобретают окказиональную отрицательную оценку и описывают неблагоприятное пространство для евреев. Ср.: 
- wasted: 'very thin because of sickness or lack of food';

- desolate: 'joyless, disconsolate, and sorrowful through or as if through separation from a loved one' (M-W).

Семы 'sickness' и 'lack of food' сигнализируют об отсутствии материального достатка и болезнях. Значительную эмоциональную нагруженность приобретают дефиниционные компоненты 'sorrowful' и 'separation from a loved one', также актуализируемые в тексте. Земля представляет собой печальное зрелище, поскольку грехи евреев отдалили их от возлюбленного (ср. библейский образ брака между избранным народом и Богом).

Особого внимания заслуживают эмоции Иисуса Христа. Согласно (Voorwinde 2011: 2), в Евангелии имеется 60 эпизодов описания эмоций Спасителя, причем в Евангелии от Иоанна их больше всего. Проблеме лингвистического описания отрицательных эмоций Христа посвящена, в частности, статья А. Вежбицкой (Wierzbicka 2018), где автор утверждает, что их адекватное толкование возможно с опорой на универсальный семантический язык. Однако в статье не ставится вопрос о сущности эмоций Спасителя, а именно: они проявления Его Божественной природы или человеческой. Приведем микроконтекст, в котором изображается печаль Иисуса Христа.

(4) 'Then when Mary was come where Jesus was, and saw him, she fell down at his feet, saying unto him, Lord, if thou hadst been here, my brother had not died. When Jesus therefore saw her weeping, and the Jews also weeping which came with her, he groaned in the spirit, and was troubled, And said, Where have ye laid him? They said unto him, Lord, come and see. Jesus wept. <...>. Jesus said, Take ye away the stone. <...>. Lazarus, come forth' (John, 11: $32-43$ ).

Эмоциональные глаголы groaned и wept описывают глубокую печаль Христа по факту смерти Лазаря. В значении этих ЛЕ имеются интенсема 'deep' и эмосемы 'grief' и 'sorrow', актуализируемые в микроконтексте. Ср.:

- groan(ed): 'to utter a deep moan indicative of pain, grief, or annoyance';

- weep (wept): 'to express deep sorrow for usually by shedding tears' (M-W).

Известно, что универсальной причиной печали является утрата чего-то значимого для человека (Ильин 2001: 170). Если не учитывать догмат о Богочеловеческой природе Иисуса Христа, то описываемая эмоция не поддается логической интерпретации. Спаситель плачет о смерти Лазаря (утрате), которого тут же воскрешает (восполнение утраты). Опора на богословский контекст позволяет снять этот алогизм. Сошлемся на богослова Иоанна Дамаскина: «Не человеческая природа оживляет Лазаря, не божественное могущество проливает слезы; ибо слеза - принадлежность человечества, а жизнь воипостасной Жизни» (Дамаскин 2002: 266). Действительно, эмоции и их физиологические корреляты сигнализируют об изменении, а любое изменение - это всегда либо деградация, либо совершенствование. Бог совершенен и деградировать не может, в противном случае речь идет не о Творце, а о человеке. 


\section{7. Репрезентация положительных эмоций}

Общеизвестно христианское учение о Боге-любви. Так, Спаситель говорит о великой любви Бога к миру, Который не пожалел Сына Своего Единородного. Апостол Иоанн прямо заявляет, что «Бог есть любовь» ('God is love') (1 John, 4: 8). Однако любовь в данном контексте не является ни эмоцией, ни чувством. Согласно Большому библейскому словарю, «это не эмоциональный отклик на красоту, заслуги или доброту, но скорее моральное отношение, пожелание блага другому, вне зависимости от того, достоин ли он любви и отвечает ли на нее» (ББС 2005: 754) (курсив мой - С.П.). Вышеприведенный эпиграф из Нового Завета вскрывает истинную сущность этой любви - неизменность Бога, творящего исключительно благо. В контексте сказанного, интересно упомянуть мнение Э. У. Дэйвиса о любви к ближнему, проповедуемой Христом, которая также не является эмоцией, а скорее бескорыстной помощью ближнему (ср. 'the love demanded by Jesus was not an emotional or mystical relationship with God; nor was it a vague, abstract love for humanity in general; rather, it entailed concrete involvement and personal action...' (Davies 2006: 742) (курсив мой - С.П.).

Соблюдение человеком заповедей Творца влечет за собой гармонию в их отношениях. Благочестивая жизнь библейского персонажа, актуализирующая первый этап сценария, репрезентируется с помощью: а) лексики с абстрактной семантикой (commandments, words, law); б) лексики с ментальной семантикой (keepth, observe, hearken, meditate); в) лексики с акциональной семантикой (not do iniquity, nor speak lies).

Атрибутируемые Богу положительные эмоции, актуализирующие второй этап сценария, репрезентируются через: а) обозначение (pleasure, love); б) описание (delight, loved, rejoice, with joy); выражение (dear, pleasant).

Третий этап сценария актуализируется посредством лексем с локальной семантикой (tree, rivers, abode, Jerusalem, Zion, vine, wine, Israel, fruit, roots, lily, corn), которые характеризуются окказиональной / узуальной положительной оценкой в микроконтекстах, репрезентирующих положительные эмоции, атрибутируемые Богу.

(5) $<<\ldots>$ if thou shalt hearken diligently unto the voice of the LORD thy God, to observe and to do all his commandments which I command thee this day, that the LORD thy God will set thee on high above all nations of the earth: And all these blessings shall come on thee, and overtake thee, if thou shalt hearken unto the voice of the LORD thy God. Blessed shalt thou be in the city, and blessed shalt thou be in the field. Blessed shall be the fruit of thy body, and the fruit of thy ground, and the fruit of thy cattle, the increase of thy kine, and the flocks of thy sheep' (Deuteronomy, 28: 1-4).

(6) 'Blessed is the man that walketh not in the counsel of the ungodly, nor standeth in the way of sinners, nor sitteth in the seat of the scornful. But his delight is in the law of the LORD; and in his law doth he meditate day and night. And he shall be like a tree planted by the rivers of water, that bringeth forth his fruit in his season; his leaf also shall not wither; and whatsoever he doeth shall prosper' (Psalm, 1: 3). 
В микроконтекстах № 5, 6 изображаются благословения, которые Бог посылает человеку за праведную жизнь. Она описывается посредством глаголов акциональной (walketh (not), (nor) standeth, (nor) sitteth) и ментальной (meditate, hearken ... unto the voice of the LORD, observe...commandments) семантики. Удаление от путей грешников (the ungodly, sinners, the scornful) и размышление над заповедями Творца (in his law doth he meditate) гарантирует человеку блаженство. Стилистическая инверсия (Blessed is the man, Blessed shalt thou be) сигнализирует об этой причинно-следственной связи и имплицирует гармоничные отношения с Богом (Его «эмоции»). Основанием для такой интерпретации отношений человека с Богом служат ЛЕ delight, LORD и law. Радость в Боге и размышление над Его законом, изображаемое гиперболой (meditate day and night), несомненно, богоугодны.

Материальное благополучие праведника изображается существительными с локальной семантикой (city, field, tree, fruit, ground, cattle, kine, sheep, rivers, fruit, leaf). Сравнение, основанное на метафорическом переносе (And he shall be like a tree planted by the rivers of water, that bringeth forth his fruit in his season; his leaf also shall not wither), а также полисиндетонная связь лексем, номинирующих достаток (city... and...field, fruit of thy body, and the fruit of thy ground, and the fruit of thy cattle, ...thy kine, and the flocks of thy sheep), создают иллюзию бесконечности благословений Бога (blessings).

(7) 'I will heal their backsliding, I will love them freely: for mine anger is turned away from him. I will be as the dew unto Israel: he shall grow as the lily, and cast forth his roots as Lebanon. His branches shall spread, and his beauty shall be as the olive tree, and his smell as Lebanon. They that dwell under his shadow shall return; they shall revive as the corn, and grow as the vine: the scent thereof shall be as the wine of Lebanon' (Hosea, 4: 7).

(8) 'The remnant of Israel shall not do iniquity, nor speak lies; neither shall a deceitful tongue be found in their mouth: for they shall feed and lie down, and none shall make them afraid. $<\ldots>$. In that day it shall be said to Jerusalem, Fear thou not: and to Zion, Let not thine hands be slack. The LORD thy God in the midst of thee is mighty; he will save, he will rejoice over thee with joy; he will rest in his love, he will joy over thee with singing' (Zephaniah, 3: $13-17)$.

В микроконтекстах № 7, 8 пророки Осия и Софония описывают возрождение и благополучие еврейского народа, который очистится от своих грехов и обратится к Богу. Лексемы с абстрактной семантикой (iniquity, deceitful, lies) в контексте отрицательных ЛЕ not, neither и nor репрезентируют благочестивую жизнь людей и нормализацию отношений с Богом. Как следствие, Бог «сменил гнев на милость» (for mine anger is turned away from him). Атрибутируемые Ему положительные эмоции любви, радости и ликования описываются глаголами love, rejoice и joy. Близость к Богу обеспечивает материальное благополучие, репрезентируемое лексемами с локальной семантикой (Israel, lily, roots, Lebanon, branches, olive tree, corn, vine, wine, Jerusalem, Zion). 
Многочисленные сравнения (as the dew, as the lily, as Lebanon, as the corn, as the vine, as the wine of Lebanon) убеждают читателя о прямой зависимости праведной жизни и материального благополучия.

(9) 'He that hath my commandments, and keepeth them, he it is that loveth me: and he that loveth me shall be loved of my Father, and I will love him, and will manifest myself to him. Judas saith unto him, not Iscariot, Lord, how is it that thou wilt manifest thyself unto us, and not unto the world? Jesus answered and said unto him, If a man love me, he will keep my words: and my Father will love him, and we will come unto him, and make our abode with him' (John 14: 21-23).

В микроконтексте № 9 изображаются наставления Иисуса Христа во время Тайной вечери. Соблюдение заповедей, маркируемое глаголом ментальной семантики keepth (keepeth them, keep my words), расценивается как проявление любви ко Христу и Богу-Отцу. Ответная любовь Бога описывается глаголом love (Father will love him). Глагол движения come, изображающий встречу Бога с человеком, сигнализирует о сокращении дистанции между ними и имплицирует их гармоничные отношения. Лексема с локальной семантикой abode (make our abode with him) репрезентирует место жительства праведника с Творцом и «овнешняет» (М.М. Бахтин) благополучие человека как результат благочестивой жизни.

\section{8. Заключение}

Исследование сложного эмотивного пространства библейского текста с холистической точки зрения является необходимым условием его осмысления, поскольку даже макроконтекст целого текста не может быть «всесильным средством, позволяющим адекватно воспринимать смысл фраз или слов» (Колшанский 1980: 92).

Постулируемая теологией и репрезентируемая в библейском тексте неизменность Бога обусловливает отсутствие у Него каких-либо эмоций. Деятельность персонажа, репрезентируемая разнооценочными лексемами с абстрактной, ментальной и акциональной семантикой и актуализирующая первый этап сценария эмоции ('причина') либо приближает его к Творцу, либо удаляет. Эти отношения интерпретируются персонажем посредством атрибуции Богу положительных / отрицательных эмоций, актуализирующих второй этап сценария ('эмоция') и репрезентируемых через номинацию, дескрипцию и экспрессию. Проведенный анализ позволил прийти к выводу о том, что языковая репрезентация отрицательных «эмоций» Бога в тексте Библии превалирует. Это объясняется тем, что библейский текст повествует в основном о неблагочестивой жизни персонажа. В качестве языковых маркеров 'реакции' на атрибутируемые Богу эмоции были рассмотрены ЛЕ с локальной семантикой, репрезентирующие библейское пространство. Данная лексика характеризуется противоположной окказиональной / узуальной 
оценочной направленностью, свидетельствует о гармонии / разладе человека с миром и имплицирует его отношения с Творцом.

\section{ПРИМЕЧАНИЕ}

Текст цитируется по изданию Библии короля Якова 1611 г. с современной английской орфографией (King James Bible). URL: https://www.kingjamesbibleonline.org/ (Accessed 09January 2019).

(C) С.М. Пашков, 2020
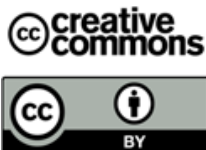

This work is licensed under a Creative Commons Attribution 4.0 International License https://creativecommons.org/licenses/by/4.0/

\section{СПИСОК ЛИТЕРАТУРЫ / REFERENCES}

Аверинцев С.С. Собрание сочинений / под ред. Н.П. Аверинцевой, К.Б. Сигова. СофияЛогос. Словарь. Київ: Дух і ліра, 2006. 902 с. [Averintsev, Sergey S. 2006. Sobranie sochinenii (Collection of works). Kiev: Dukh i litera. (In Russ.)].

Бахтин М.М. Эстетика словесного творчества. М.: Искусство, 1986. 445 с. [Bakhtin, Mikhail M. 1986. Estetika slovesnogo tvorchestva (The Aesthetics of Verbal Art). Moscow: Iskusstvo. (In Russ.)].

Бобырева Е.В. Когнитивно-эмоциональное пространство религиозной коммуникации // Вестник Тюменского государственного университета. Гуманитарные исследования. Humanitates T. 1, № 2 (2). 2015. C. 51-59. [Bobyreva, Ekaterina V. 2015. Kognitivno-emotsional'noe prostranstvo religioznoi kommunikatsii (Cognitive-emotional space of religious communication) Vestnik Tyumenskogo gosudarstvennogo universiteta. Gumanitarnye issledovaniya 1. 2 (2). 51-59. (In Russ.)].

Волкова Я.А, Панченко Н.Н. Дискурсивная вариативность концептов деструктивных эмоций // Вестник РУДН. Серия: Лингвистика. 2018. Т. 22. № 1. С. 175-194. [Volkova, Yana A. \& Nadezhda N. Panchenko. 2018. Discourse variation of the concepts of destructive emotions. Russian Journal of Linguistics 22 (1). 175-194. (In Russ.)]. DOI: $10.22363 / 2312-9182-2018-22-1-175-194$.

Гальперин И.Р. Текст как объект лингвистического исследования. М.: КомКнига, 2007. 144 c. [Gal'perin, Ilia R. 2007.Tekst kak ob"ekt lingvisticheskogo issledovaniya (Text as an object of linguistic research). Moscow: KomKniga. (In Russ.)].

Дамаскин И. Источник знания. М.: Индрик, 2002. 416 с. [Damaskin, Ioann. 2002. Istochnik znaniya (The Source of knowledge). Moscow: Indrik. (In Russ.)].

Ильин Е.П. Эмоции и чувства. СПб.: Питер, 2001. 752 с. [Il'in, Evgeniy P. 2001. Emotsii i chuvstva (Emotions and feelings). Saint Petersburg: Piter. (In Russ.)].

Ильин И.А. Аксиомы религиозного опыта. М.: ООО «Издательство АСТ», 2002. 586 с. [Il'in, Ivan A. 2002. Aksiomy religioznogo opyta (Axioms of Religious Experience). Moscow: OOO «Izdatel'stvo ACT». (In Russ.)].

Карасик В.И. Языковой круг: личность, концепты, дискурс. Волгоград: Перемена. 2002. 477 c. [Karasik, Vladimir I. 2002. Yazykovoi krug: lichnost', kontsepty, diskurs (Language circle: personality, concepts, discourse). Volgograd: Peremena. (In Russ.)]. 
Князева Е.Н. Возвращение к единству: методологические аспекты эволюционного холизма // Вестник Томского государственного университета. Философия. Социология. Политология. 2016, № 3 (35). С. 23-35. [Knyazeva, Elena N. 2016. Vozvrashchenie k edinstvu: metodologicheskie aspekty evolyutsionnogo kholizma (Return to unity: the methodological aspects of evolutionary holism). Vestnik Tomskogo gosudarstvennogo universiteta. Filosofiya. Sotsiologiya. Politologiya 3 (35). 23-35. (In Russ.)]. DOI: 10.17223/1998863X/35/2.

Колшанский Г.В. Контекстная семантика. М.: «Наука», 1980. 147 с. [Kolshanskii, Gennadiy V. 1980. Kontekstnaya semantika (Contextual semantics). Moscow : Nauka. (In Russ.)].

Леонтьев А.Н. Эмоции // Философская энциклопедия / под ред. В.Ф. Константинова. Т. 5. М.: Советская энциклопедия, 1970. С. 553-555. [Leont'ev, Aleksey N. 1970. Emotsii (Emotions), 5. 553-555. Encyclopedia of philosophy. Moscow (In Russ.)].

Найденова Н.С. Современная лингвистика в постсекулярной перспективе // Вестник РУДН. Серия: Лингвистика. 2018. Т. 22, № 4. С. 998-1000. [Najdenova, Natalia S. 2018. Modern Linguistics through Post-Secular Perspective. Russian Journal of Linguistics 22 (4). 998-1000. (In Russ.)]. DOI: 10.22363/2312-9182-2018-22-4-9881000 .

Осипов А.И. Бог. 4-е изд. М.: Православное братство святого апостола Иоанна Богослова, 2014. 104 c. [Osipov, Aleksey I. 2014. Bog (God). Moscow: Pravoslavnoe bratstvo svyatogo apostola Ioanna Bogoslova. (In Russ.)].

Пашков С.М. Языковые средства репрезентации нуминозных эмоций (на материале англоязычного текста Библии) // Вестник Волгоградского государственного университета. Серия 2, Языкознание. 2018. Т. 17, № 1. С. 52 -62. [Pashkov, Sergey M. 2018. Yazykovye sredstva reprezentatsii numinoznykh emotsii (na materiale angloyazychnogo teksta Biblii) (Language means of representing numinous emotions (based on the material of the English Bible text). Vestnik Volgogradskogo gosudarstvennogo universiteta. Seriya 2, Yazykoznanie 17 (1). 52-62. (In Russ.)]. DOI: https://doi.org/10.15688/ jvolsu2.2018.1.6.

Топоров В.Н. Пространство и текст // Текст: Семантика и структура / под ред. Т.В. Цивьян. М.: «Наука», 1983. С. 227-285. [Toporov, Vladimir N. 1983. Prostranstvo i tekst (Space and text). Tekst: Semantika i struktura (Text: Semantics and structure). Moscow: Nauka. (In Russ.)].

Щирова И.А. Психологический текст: деталь и образ. СПб.: Филологический факультет Санкт-ПбГУ, 2003. 120 c. [Shchirova, Irina A. 2003. Psikhologicheskii tekst: detal' $i$ obraz (Psychological text: detail and image). Saint-Petersburg: Filologicheskii fakul'tet Sankt-PbGU. (In Russ.)].

Филимонова О.Е. Эмоциология текста. Анализ репрезентации эмоций в английском тексте СПб.: ООО «Книжный Дом», 2007. 448 с. [Filimonova, Olga E. 2007. Emotsiologiya teksta. Analiz reprezentatsii emotsii v angliiskom tekste (Emotiology of text. Analysis of emotion representation in English text). Saint-Petersburg: OOO «Knizhnyi Dom». (In Russ.)].

Шаховский В.И. Категоризация эмоций в лексико-семантической системе языка. М.: ЛИБРОКОМ. 2009. 208 с. [Shakhovskii, Victor I. 2009. Kategorizatsiya emotsii $v$ leksiko-semanticheskoi sisteme yazyka (Categorization of emotions in lexico-semantic system of language). Moscow: LIBROKOM. (In Russ.)].

Шаховский В.И. Эмоции: Долингвистика, лингвистика, лингвокультурология. М.: ЛИБРОКОМ. 2010. 128 с. [Shakhovskii, Victor I. 2010. Emotsii: Dolingvistika, lingvistika, lingvokul'turologiya (Emotions: Pre-linguistics, linguistics, linguage-cultural studies). Moscow: LIBROKOM. (In Russ.)]. 
Яковлева Е.С. Фрагменты русской языковой картины мира (модели пространства, времени и восприятия). М.: «Гнозис», 1994. 344 с. [Yakovleva, Elena S. 1994. Fragmenty russkoi yazykovoi kartiny mira (modeli prostranstva, vremeni $i$ vospriyatiya) (Fragments of Russian language world picture (models of space, time and perception)). Moscow: «Gnozis». (In Russ.)].

Davies, Eryl W. 2006. The Bible in Ethics. In John W. Rogerson \& Judith M. Lieu (eds.). The Oxford handbook of Biblical studies, 732-753. Oxford: Oxford University Press.

Extrom, Laura W. 2012. Suffering as a religious experience. In Louis P. Pojman \& Michael Rea (eds.), Philosophy of Religion: An Anthology. 6th edn., 392-401. USA: Cengage Learning.

Kövecses, Zoltán, Gary B. Palmer \& René Dirven. 2003. Language and emotion: The interplay of conceptualisation with physiology and culture. In René Dirven \& R. Pörings (eds.), Metaphor and Metonymy in Comparison and Contrast, 133-159. Berlin/New York: Mounton de Gruyter.

Kövesces, Zoltán 2000. Metaphor and emotion. Language, Culture, and Body in Human Feeling. Cambridge: Cambridge University Press.

Marx, Stephen. 2000. Shakespeare and the Bible. Oxford/New York: Oxford University Press.

North, Robert. 2001. Adam. In Bruce M. Metzger \& Michael D. Coogan (eds.), The Oxford guide to people \& places in the Bible, 3. Oxford/New York: Oxford University Press.

Pojman, Louis P. \& Michael Rea. (eds.). 2012. Philosophy of Religion: An Anthology. 6th edn. 60. USA: Cengage Learning.

Voorwinde, Stephen. 2011. Jesus' Emotions in the Gospels. London: T\&T Clark.

Werblowsky, Zwi R. J. 2005. Anthropomorphism. In Jones Lindsay (eds.), Encyclopedia of religion. 2nd edn. 1. 388-392. USA: Thomson Gale.

Whybray, Roger N. 2000. Genesis. In John Barton \& John Muddiman (eds.), The Oxford Bible Commentary, 38 - 66. Oxford: Oxford University Press.

Wierzbicka, Anna. 1992. Defining emotion concepts. Cognitive science 16. 539-581.

Wierzbicka, Anna. 2018. Emotions of Jesus. Russian Journal of Linguistics 22 (1). 38-53. DOI: $10.22363 / 2312-9182-2018-22-1-38-53$.

Zlatev, Jordan. 2007. Spatial Semantics. In Hubert Cuyckens \& Dirk Geeraerts (eds.), The Oxford Handbook of Cognitive linguistics, 318-350. Oxford: Oxford University Press.

\section{СЛОВАРИ И ИНTЕPHET-PEСУРСЫ / DICTIONARIES AND INTERNET RESOURSES}

ББС - Больиой библейский словарь / под ред. У. Элуэлла, Ф. Камфорта. 2005 / СПб.: Библия для всех. 1503 с. [Bol'shoi bibleiskii slovar' pod red. U. Eluella, F. Kamforta. SPb.: Bibliya dlya vsekh. 2005].

Мень А. Библиологический словарь. Т. 2. М.: Фонд имени Александра Меня, 2002. [Men', A. 2002. Bibliologicheskii slovar', T. 2. M.: Fond imeni Aleksandra Menya, 2002].

Словарь библейского богословия / под ред. К. Леон-Дюфуа. 1990 / Bruxelles: «Жизнь с Богом». 1287 c. [Slovar' bibleiskogo bogosloviya pod red. K. Leon-Dyufua. Bruxelles: «Zhizn' s Bogom». 1990].

Ожегов С.И., Шведова Н.Ю. Толковый словарь русского языка. М.: «Азбуковник», 1997. [Ozhegov, Sergey, Nataliya Shvedova. 1997. Tolkovyi slovar' russkogo yazyka. M.: Azbukovnik.].

Большой психологический словарь / под ред. Б.Г. Мещерякова, В.П. Зинченко. М.: Прайм-Еврознак, 2003. 633 с. [Bol'shoi psikhologicheskii slovar' / pod red. B.G. Meshcheryakova, V.P. Zinchenko. M.: Praim-Evroznak, 2003].

M-W - Merriam — Webster Dictionary. URL: http://www.merriamwebster.com. Accessed on January 15, 2019. 
Article history:

Received: 17 January 2019

Revised: 12 April 2019

Accepted: 25 January 2020

\section{История статьи:}

Дата поступления в редакцию: 17 января 2019

Дата принятия к печати: 25 января 2020

\section{Сведения об авторе:}

ПАШКОВ СЕРГЕЙ МИХАЙЛОВИЧ — кандидат филологических наук, доценТ кафедры гуманитарного образования и педагогических технологий, Российский государственный педагогический университет (РГПУ им. А.И. Герцена, Волховский филиал). Сфера научных интересов: лингвистика текста, интерпретация текста, стилистика, лингвистика эмоций, религиозный дискурс.

\section{Контактная информация:}

Российский государственный педагогический университет им. А.И. Герцена (Волховский филиал)

187400, Россия, г. Волхов, ул. Октябрьская набережная, д. 1 а.

e-mail: vlingua2010@mail.ru

SPIN-RSCI: 7850-9040

ORCID ID: 0000-0002-7552-7304

\section{Bionote:}

SERGEY M. PASHKOV, PhD, Associate Professor, Department of Humanities, Education and Educational Technologies, Saint Petersburg State Pedagogical University (Volkhov Branch). His research interests include text studies, text interpretation, stylistics, emotiology and religious discourse.

\section{Contact information:}

Herzen State Pedagogical University (Volkhov branch)

1a Oktyabrskaya naberezhnaya St., Volkhov, 187403, Russia

e-mail: vlingua2010@mail.ru

SPIN-RSCI: 7850-9040

ORCID ID: 0000-0002-7552-7304 